This is the accepted version of "Albitar, Khaldoon, Al-shaer, Habiba and Elmarzouky, Mahmoud (2021) Do assurance and assurance providers enhance COVID-related disclosures in CSR reports? An examination in the UK context. International Journal of Accounting \& Information Management, 29(3), pp. 410-428", available at https://www.emerald.com/insight/content/doi/10.1108/IJAIM-01-2021-0020/full/html

c 2021, Emerald Publishing Limited. This AAM is provided for your own personal use only. It may not be used for resale, reprinting, systematic distribution, emailing, or for any other commercial purpose without the permission of the publisher. 


\title{
DO ASSURANCE AND ASSURANCE PROVIDERS ENHANCE COVID-RELATED DISCLOSURES IN CSR REPORTS? AN EXAMINATION IN THE UK CONTEXT
}

\author{
Albitar, K., Al-Shaer, H. and Elmarzouky, M., 2021. Do Assurance and Assurance Providers Enhance \\ Covid-Related Disclosures In CSR Reports? An Examination In The UK Context. International \\ Journal of Accounting and Information Management.
}

\begin{abstract}
Purpose: The COVID-19 pandemic has been adding pressures on companies to commit to their social and ethical responsibilities. CSR reporting is the main tool through which companies communicate their social behaviour and the need for credible information is censorious during the crisis. This paper aims to measure the level of COVID-19 disclosures in CSR reports by using an automated textual analysis technique based on a sample of UK companies and investigate whether the level of disclosure is enhanced for companies that subject their CSR reports to an assurance process.
\end{abstract}

Design/methodology/approach: Our sample consists of FTSE All-share non-financial listed companies. We employ a computer-aided textual analysis and we use a bag of words to capture COVID-related information in the CSR section of the firm's annual reports.

Findings: The results suggest that the existence of independent external assurance is significantly and positively associated with the provision of COVID-19 information in CSR reports. We also find that when assurance is provided by Big 4 accountancy firm, the disclosure of COVID-related information is enhanced. Furthermore, large companies are more likely to disclose COVID-related information in their CSR reports that are externally assured from top tier accountancy firms suggesting that assurance could be a burden for smaller firms. Overall, the findings suggest that assurance on CSR reports provides an 'insurance-like' protection that mitigates the risks and signals the management's ethical behaviour during the pandemic.

Practical implications: Our approach helps to assess the level of corporate engagement with COVID-19 practices and the extent of related disclosures in CSR reports based on the Covid19 Secure Guidelines published by the UK government. This helps to emphasise how companies engage and communicate Covid-19 related information to stakeholders through CSR reports and ensure a safe working environment during this pandemic. Managers will need to assess the costs and benefits of purchasing assurance on CSR disclosures giving the ethical signal that assurance sends to the market and protection that it covers during the crisis.

Originality/value: This paper provides a shred of unique evidence of the impact of the existence of external assurance and the type of assurer on the disclosure of COVID-related information in CSR reports. To the best of our knowledge, no study has yet investigated the corporate disclosure on an unforeseen event in CSR reports and the role of CSR assurance in this respect. 
Keywords: COVID-19, assurance, corporate social responsibility (CSR), disclosure, textual analysis.

\section{INTRODUCTION}

COVID-19 pandemic has had considerable economic and financial effects worldwide and is considered the toughest challenge since the great depression (He and Harris 2020; Goodell, 2020; Albitar et al., 2020a; Amankwah-Amoah, 2020). Managers are facing challenging decisions regarding their social and ethical behaviour during the pandemic and they need to respond proactively to protect their employees and customers (Levy, 2020). Governments and decision-makers worldwide have established economic and financial measures to help companies under strain from the COVID-19 pandemic. These measures should encourage companies to maintain ethical business practices and fulfil their CSR commitments to all stakeholders (He and Harris 2020). The UK government has issued COVID-19 safety guidelines to ensure a safe working environment (GOV.UK, 2020) and companies will need to follow these guidelines to ensure the safety of their employees, customers, and work environment. Nevertheless, companies are expected to disclose information related to COVID-19 prevention strategies to reduce information asymmetry and signal their performance to the market. Despite the fact that these practices are not strictly enforced, companies' provision of COVID-related information signals their ethical behaviour and how they operate during such a turbulent environment due to COVID-19 pandemic.

Recent research investigating the effect of COVID-19 pandemic has mostly focused on market reactions (Erdem, 2020; Mazur et al., 2020; Salisu and Vo, 2020; Hossain, 2020) and provided theoretical perceptions of the impact of COVID-19 pandemic on financial markets, banking and insurance companies, CSR, auditing, and government and public sector (Goodell, 2020; Donthu and Gustafsson, 2020; Albitar et al., 2020a; He and Harris 2020; Levy, 
2020). Other work has focused on the impact of COVID-19 pandemic on environmental awareness, sustainable consumption, and social responsibility (Severo et al., 2020) and the effect of ESG disclosures on corporate financial performance during the COVID-19 crisis (Broadstock et al., 2020). To the best of our knowledge, no study has yet investigated the corporate disclosure on an unforeseen event in CSR reports and the role of CSR assurance in this respect.

Our paper adds to the existing literature on the external assurance of CSR reports (e.g., Cohen and Simnett, 2015; Ballou et al., 2018; Clarkson et al., 2019; Du and Wu, 2019; Hassan et al., 2020; Ruiz-Barbadillo and Martínez-Ferrero, 2020), and is motivated by studies that reflect on the role of CSR assurance in negative event situations. For example, Pflugrath et al. (2011) show that CSR assurance enhances credibility of CSR reports issued after a negative event, and Stuart et al. (2020) show that purchasing assurance on CSR reports signals management's ethical culture and provides 'insurance-like' protection from any potential reaction to future negative incidents. The motivation of our study is to examine whether CSR assurance choices (i.e., the purchase of assurance and assurance provider) enhance the extent of COVID-related disclosures in CSR reports during the COVID-19 crisis. The incentive to purchase voluntary assurance services can be framed in the context of the signalling theory. Assurance can signal that CSR information is reliable and increase the transparency and credibility of information (Simnett et al., 2009; Cohen and Simnett, 2015; Peters and Romi, 2015).

Due to COVID-19 pandemic, companies face challenging decisions regarding social performance and ethical thinking, and they need to conduct COVID prevention strategies to protect their employees and customers (Levy, 2020; Manuel and Herron, 2020). This paper aims to assess the degree of corporate disclosure on the COVID-19 pandemic in CSR reports and investigate whether such disclosure is improved for companies that subject their CSR 
reports to an assurance process. We contribute to the CSR assurance literature in several ways. First, we employ a computer-aided textual analysis technique to examine COVID-19 disclosures in CSR reports of UK companies. The use of textual analysis for qualitative information has been applied in several studies, and its importance is being recognised by different researchers (Clarkson et al., 2020; Andreou et al., 2020; Elmarzouky et al. 2020). Second, we investigate the impact of the existence of external assurance and the type of assurer on the disclosure of COVID-related information in CSR reports. As a result, we examine the role that CSR assurance could play during a negative event. Third, we investigate whether there is a heterogeneity in the effect of assurance and assurance provider and COVID19 related disclosures in CSR reports when comparing big and small firms due to recourse implications during the pandemic.

Using a sample of UK firms that published their annual reports in 2020, we assess the degree of COVID-related disclosures in CSR reports and find that the existence of independent external assurance has a positive and significant association with COVID-related information measured using both the frequency of COVID-related words appearing in the reports and a dummy variable. We also find that when assurance is provided by Big4 accountancy firm, the disclosure of COVID-related information is enhanced. When we divide the sample into large and small firms, our result suggests that large companies are more likely to disclose COVID-related information in their CSR reports that are externally assured by a Big4 accountancy firm because they have the required resources to cover such cost than smaller firms. We further explore the influence of CSR-sensitive industries on the impact of CSR assurance and assurance provider on COVID-related disclosures, and our results are consistent.

The remainder of this paper is structured as follows. Section 2 provides a theoretical framework and develops the study's hypotheses. Section 3 describes the study's methodology, 
including variable measurement, model specification, and sample selection. Section 4 analyses the study's findings. Finally, Section 5 concludes.

\section{THEORY AND HYPOTHESES DEVELOPMENT}

CSR reporting has attracted considerable attention from the academic community (Ballou et al. 2018; Boiral et al., 2019; Michelon et al. 2019). Studies show that assurance of CSR reports reduces stakeholders' pressures because it enhances transparency and increases reporting quality (Ballou et al., 2018; Martínez-Ferrero et al., 2018; Boiral et al., 2019). It can also improve the credibility and reliability of CSR reports (Simnett et al. 2009; Birkey et al., 2016; Du and Wu, 2019; Hassan et al., 2020). The voluntary assurance of CSR reports will encourage firms to disclose more reliable and accurate information and strengthen companies' commitment to sustainability (Cohen and Simnett, 2015; Birkey et al., 2016; Ballou et al., 2018; Hassan et al., 2020).

According to the signalling theory, companies with a proactive strategy and better ethical and social performance have incentives to provide more information to stakeholders to signal their positive practices and concerns for the environment and society (Clarkson et al., 2019). These companies will be willing to assure their CSR reports to signal stakeholders their commitment to sustainability (Mahoney et al., 2013; Gerged et al., 2018). Signalling theory suggests that while engaging in CSR assurance can impose costs, companies will buy assurance when the benefits outweigh the associated costs (Bangoli and Watts, 2017; Hassan et al., 2020). Companies may purchase assurance for their CSR reports to signal that they are socially responsible corporate citizen (Bagnoli and Watts, 2017; Hassan et al., 2020). Moreover, companies that voluntarily purchase professional assurance on a voluntary disclosure can distinguish themselves from less socially responsible companies (Clarkson et al., 2015) and 
they choose to obtain high-quality assurance to distinguish their levels of socially responsible activities (Bagnoli and Watts, 2017).

Assurance provider can play a crucial role in enhancing the quality of CSR reports (Martínez-Ferrero et al., 2018; Du and Wu, 2019; Hassan et al., 2020). In the UK institutional setting, firms can purchase assurance services from a wide variety of providers such as Big4 accounting firms (Deloitte, E.Y., KPMG, and PwC), non-Big4 accounting firms (e.g., Grant Thornton), and specialist consultant and engineering services firms (e.g., Bureau Veritas). ${ }^{1}$ Assurance providers can vary in their background and expertise (Perego and Kolk, 2012). In the absence of generally accepted reporting standards for CSR reporting and the complexity of CSR reporting content, high skilled assurance provider is required to enhance the quality of CSR reports (Cohen and Simnett, 2015; Martínez-Ferrero et al., 2018). Research shows that top tier accountancy firms are more likely to provide higher quality assurance services because those firms have better experience in conducting detailed tests and analytical procedures (Gürtürk and Hahn, 2016; Farooq and de Villiers, 2019). CSR reports that have been assured by top tier accounting firms will have higher credibility because those firms have better expertise in risk assessment and consideration of materiality in providing assurance (Al-Shaer and Zaman 2019; Hummel et al., 2019). This can ease stakeholders' concerns about the transparency of CSR reports and enhance their confidence (Simnett et al., 2009; MartínezFerrero et al., 2018; Hassan et al., 2020; Boiral and Heras-Saizarbitoria, 2020).

Even though CSR assurance has attracted considerable attention from the academic community, more research work is deemed necessary to further investigate whether CSR assurance contributes to the provision of COVID-related disclosures in CSR reports.

\footnotetext{
1The International Federation of Accountants (IFAC) defines third-party assurance as "an engagement in which a practitioner expresses a conclusion designed to enhance the degree of confidence of the intended users other than the responsible party about the outcome of the evaluation or measurement of a subject matter against criteria." See International Standard on Assurance Engagements, 2013. ISAE 3000 Revised - for IAASB.pdf (ifac.org).
} 
Stakeholders are demanding companies to disclose information in relation to COVIDprevention strategies and to explain their social and ethical behaviour during this pandemic (Broadstock et al., 2020; Levy, 2020). We would therefore expect that, according to signalling theory, companies that disclose COVID-related information in their CSR reports will purchase assurance to signal that the company is a socially responsible corporate citizen (Bagnoli and Watts, 2017). Companies will need to signal their ethical behaviour during the pandemic through CSR disclosures to show that they are creating COVID-secure environment for their employees, customers, and the public. Under these volatile conditions, we have seen many initiatives by the UK governments, professional bodies, and the Financial Reporting Council (FRC) to help firms deal with the pandemic which may affect the provision of COVID-19 related information through corporate reporting (Albitar et al., 2020a). However, there is no mandatory requirement for entities to disclose information on facilitating a COVID-secure environment to protect their stakeholders. In light of the aforementioned discussion of the role of external assurance and assurance provider in enhancing the transparency and credibility of CSR disclosures, we investigate the association between the adoption of external assurance and type of assurer and the provision of COVID-related disclosures in CSR reports and propose the following hypotheses:

H1: Ceteris paribus, there is an association between the adoption of CSR assurance and COVID-related disclosures in CSR reports.

H2: Ceteris paribus, there is an association between CSR assurance provider and COVID-related disclosures in CSR reports.

Company size is one of main factor that has an impact on political vulnerability since size represents the public presence, and large companies have the time and resources needed for voluntary disclosure (Milne, 2002). Larger companies, or those most visible, face reputational challenges that smaller and less visible companies do not. The profiles of these 
companies give rise to the incurrence of costs necessary to manage these reputation challenges, which Watts \& Zimmerman (1979) referred to as political costs. These might include, inter alia, the need to manage reputation with a range of initiatives including the voluntary disclosure of areas of interest to those demanding information or reassurances. Industry also attracts public attention especially certain industries that engage in activities with substantial impact on society or the environment. Certain industries endure high regulatory costs or contain large companies that make high profit and thus attract public attention (Milne, 2002).

It is likely that legitimacy-based explanations are based on similar suppositions to political costs in that those companies with a specific size or activity vulnerabilities have been found to disclose more in those areas, conceivably to offset, nullify or address legitimacy gaps. In keeping with a legitimacy-based explanation, legitimacy gaps are more likely to open up when there is a pre-existing vulnerability occasioned by public exposure or industry sector (Deegan et al., 2000; Campbell, 2003). Stakeholders exhibit greater pressure on companies that are more visible. Voluntary disclosure of highly visible companies could help achieve legitimacy and gain public image (Dawkins and Fraas, 2011; Albitar et al., 2020b; Li et al., 2020). According to resource-based view framework, companies with resource endowments, such as greater size with higher profit invest in specific competitive advantage generating resources and engage in projects, including CSR projects (Barney et al., 2001; Russo and Fouts, 1997; Li et al., 2020; Liao et al., 2020). Several studies show that larger companies are more likely to adopt assurance (Simnett et al., 2009; Zorio et al. 2013; Fernandez-Feijoo et al. 2015). Big-sized firms are more likely to produce CSR reports and obtain higher quality assurance than small-sized firms since they have the required resources to do so. Furthermore, the cost of socially responsible activities differs across industries because of the use of different production technologies and facilities. Firms in mining industries or those whose production 
facilities are suspected of offering poor working conditions are under greater scrutiny and are more likely to purchase higher quality assurance (Bagnoli and Watts, 2017). Based on the above discussion, we propose the following hypothesis:

H3: Ceteris paribus, there is heterogeneity in the impact of assurance and assurance provider on COVID-related disclosures in CSR reports when considering different firms' size and different CSR sensitive industries.

\section{RESEARCH METHODS}

\subsection{Sample}

We use a sample of FTSE All-share non-financial listed companies that their annual reports were published in 2020. We downloaded the annual reports from companies' websites. We mainly focused on CSR's narrative reporting as this has been claimed to be an effective means of communication between managers and stakeholders (Barkemeyer et al. 2014; Fisher et al., 2019). To extract the CSR narrative sections in annual reports, we use an automated textual analysis technique and utilise the Corporate Financial Information Environment (CFIE) software created by Lancaster University. CFIE is a research programme that explores accounting and financial market text using natural language processing and corpus linguistics methods (El-Haj et al., 2019). We exploit it to score the COVID-19 disclosure in CSR reports. We collect other related variables from Eikon database.

\subsection{Dependent Variable}

To measure COVID-19 disclosures in CSR reports, we followed previous literature for constructing a bag of words in the domain of narrative disclosures (Linsley and Shrives 2006; Loughran and McDonald, 2011; Andreou et al., 2020). We use the wordlist developed by Elmarzouky et al. (2020) that is constructed based on the Covid-19 Secure Guidelines published by the UK Government (GOV.UK, 2020). We score the annual reports using the 
CFIE software. We double-check the score manually for a random sample of CSR reports to assess the reliability of the measurement. The results remain consistence. Following Elmarzouky et al. (2020), we also used Nvivo 12 pro as another validation of the measurement by re-scoring a random sample of CSR reports, and the results remain consistence. Appendix 1 shows an examples of the original word list used for measuring COVID-19 disclosure.

\subsection{Explanatory Variables}

External assurance helps enhance information transparency and increase the completeness and credibility of CSR reports (Hodge et al., 2009; Pflugrath et al., 2011; Zorio et al., 2013; Al-Shaer and Zaman, 2018). Our variables of interest are the existence of external assurance and type of assurer. CSR_assurance is measured using a dummy variable equal to 1 if CSR disclosure is externally assured and zero otherwise. Prior literature argues that assurance service is perceived to be higher when assurance provider is a top tier accountancy firm (Junior et al., 2014; Al-Shaer and Zaman, 2018). Assurance provider (Assurance_type) is measured using a scale where Assurance_type equals 3 if assurance is provided by Big4 accounting firm, 2 if assurance is provided by non-Big4 accounting firm, 1 if assurance is provided by non-accounting firm, 0 if no assurance service is provided. This scaling will allow us to provide preliminary evidence on whether assurance quality affects the disclosure of COVID-related information in CSR reports.

Prior literature shows a link between governance variables and CSR disclosure (Husted and de Sousa-Filho, 2019; Al-Shaer et al., 2017; Majumder et al., 2017; Ullah et al., 2019; Chan et al., 2020). We thus include some corporate governance variables. We expect that the existence of board-level CSR committee, measured using a dummy variable equals 1 if a committee exists and zero otherwise, to impact the disclosure of COVID-related information in CSR reports. We also include board size (BODSIZE) measured by the number of board members, board independence (BODIND) measured by the proportion of independent 
directors on the board, and board diversity (BODDIV) measured by the proportion of female directors on the board.

Prior literature suggests it is important to control for firm-specific characteristics when examining CSR reporting (Simnett et al. 2009; Nazari et al., 2017; Muslu et al., 2019). Larger firms with greater resources have opportunities to increase the scale and scope of their social and environmental activities and to disclose them (Al-Shaer et al., 2017). We control for firm size measured by the natural log of total assets. Firm resources are represented by profitability measured by return on assets (ROA) and TOBINSQ calculated by dividing the sum of firm equity value, book value of long-term debt, and current liabilities by total assets. We also control for financial leverage (LEV) measured by debt to total assets ratio, representing the firm's risk perception, and firm loss (LOSS) using an indicator variable equals one when the current year's net income is negative and zero otherwise. We control the firm's CSR performance in the previous year (ESG_perf) measured using the ESG score from ASSET4 database. Finally, we control for the length of a document (Length) measured by the natural log of total word count in the CSR section and industry by grouping firms in the sample using the one-digit Standard Industry Classification (SIC) codes.

\subsection{Empirical Model}

We construct the multivariate regression model below to examine the association between the adoption of external assurance and assurance provider and the provision of COVID-related disclosures in CSR reports. The variables used in this study are defined in Table I. Industry dummies are created based on the SIC one-digit industry classification.

$$
\begin{aligned}
\text { COVID }_{\text {score }}= & \beta_{0}+\beta_{1} \text { CSR }_{\text {assurance }}+\beta_{2} \text { Assurance }_{\text {type }}+\beta_{3} \text { CSR }_{\text {committee }}+\beta_{4} \text { ESG }_{\text {perf }} \\
& +\beta_{5} \text { BODSIZE }+\beta_{6} \text { BODIND }+\beta_{7} \text { BODDIV }+\beta_{8} L E V+\beta_{9} \text { ROA }+\beta_{10} \text { TOBINSQ } \\
& +\beta_{11} \text { LOSS }+\beta_{12} \text { SIZE }+\beta_{13} \text { Length }+\beta_{14} \text { Industry dummies }+\epsilon
\end{aligned}
$$




\section{[Table I about here]}

\section{EMPIRICAL RESULTS}

\subsection{Descriptive Statistics}

Table II reports descriptive statistics for key variables in our model. The mean value of COVID_score is 1.646 representing the average frequency of COVID_relared words disclosed in the CSR section, where the minimum number of words is zero, and the maximum is 40 words indicating that the majority of our sample companies have a low level of COVID related information in the CSR reports. During the pandemic, companies are facing a challenging situation and few companies have clear strategies of how to maintain social behaviour and ethical thinking to protect their employees and customers. The mean value of COVID_dummy is 0.333 , indicating that on average, $33 \%$ of our sample firms disclose COVIDrelated information in the CSR reports. The mean value of CSR_assurance 0.659 indicating that on average, $66 \%$ of our sample firms get their report externally assured and the mean value of Assurance_type is 1.984 suggesting that a large proportion of our sample firms have independent external assurance from non-Big4 accounting firms. The mean value of CSR_committee is 0.728 and suggests that on average, $73 \%$ of our sample firms have a separate CSR committee. We find the mean board size (BODSIZE) is 8.584, board independence (BODIND) is 0.608 which means that on average, two-thirds of our sample firms have independent directors, and on average, $28.4 \%$ of board members are females. The mean value of ESG_perf is 102.491. Regarding firm-specific variables, we find the mean firm size (SIZE) is $£ 8,380,000,000$, return on assets (ROA) is 0.047 , TOBINSQ is 0.878 , leverage is 0.690 , and LOSS is 0.156 which suggests that on average, $16 \%$ of our sample firms reported a loss. 


\section{[Table II about here]}

Table III reports the Pearson correlation matrix for variables used in our analysis. We find that CSR_assurance, Assurance_type, CSR_committee, ESG_perf, BODDIV, and SIZE are positively correlated with COVID_dummy, indicating a significant overall positive association. The Pearson correlation coefficients provided in Table III do not evidence serious multicollinearity problems. The variance inflation factor (VIF) ranges between 1.15 (lowest value) and 2.24 (highest value), and the average value is 1.60 . This also suggests the absence of multicollinearity. ${ }^{2}$

\section{[Table III about here]}

\subsection{Multivariate Analysis}

We report the findings of our regression tests in this section. COVID_score is a count variable, and thus we use negative binomial specification, and COVID_dummy is a dichotomous variable, and thus we use probit regression. Table IV shows that CSR_assurance has a positive and significant association with COVID_score at 5\% level (coeff $=1.2418, t=2.21$ ) and with COVID_dummy at $5 \%$ level (coeff $=0.7095, t=1.98)$. Assurance_type has a positive and significant association with COVID_score at $1 \%$ level (coeff $=0.5399, t=2.69)$ and with COVID_dummy at $1 \%$ level (coeff $=0.5453, t=3.03) .{ }^{3}$ Our finding supports our hypotheses that when companies provide independent external assurance of their CSR reports and when the assurance provider is a Big4 accounting firm, they are more likely to disclose COVID-related information. Additionally, we find that BODDIV has a positive and significant association with COVID_score at 5\% level (coeff $=4.4199, t=2.50)$ and COVID_dummy at $1 \%$ level

\footnotetext{
2 We conduct similar correlations when using COVID_score as the dependent variable (untabulated).

${ }^{3}$ CSR_committee, on the other hand, do not show to have an impact on both COVID_score and COVID_dummy possibly due to the lack of significant variations in the values of this variable in our regression tests.
} 
(coeff $=4.0573, t=3.28)$ suggesting that when firms have more female directors on the board, they would have stronger corporate governance. As a result, the disclosure of COVID-related information is more pronounced. Based on the theoretical perspective from signalling theory, our finding supports the argument that companies that provide disclosures on CSR information will purchase assurance to signal that the company is a socially responsible corporate citizen (Bagnoli and Watts, 2017). CSR assurance signals a positive ethical culture and provides an 'insurance-like' protection during times of crisis (Stuart et al., 2020).

\section{[Table IV about here]}

In Table $\mathrm{V}$, we divide the sample into small-sized firms and big-sized firms based on the median to check whether our results are impacted by the size factor. Splitting the sample into small and large-sized firms helps analyse the effect of independent external assurance and assurance provider beyond any size effect. Our result for the sample of large firm shows that CSR_assurance has a positive and significant association with COVID_score at $10 \%$ level (coeff=1.644, $t=1.74)$, and with COVID_dummy at $5 \%$ level (coeff=1.6097, $t=2.32$ ). Assurance_type has also positive and significant association with COVID_score at 5\% level (coeff $=0.5357, t=1.69$ ) and with COVID_dummy at 5\% level (coeff=0.5394, $t=2.12$ ). Among corporate governance variables, we find BODSIZE have a positive and significant association with COVID_score at $10 \%$ level (coeff $=1.7434, t=1.70$ ) and with COVID_dummy at 5\% level (coeff=0.2761, $t=2.46)$ and BODDIV has a positive and significant association with COVID_score at $1 \%$ level (coeff=8.6329, $t=2.87$ ) and with COVID_dummy at $5 \%$ level (coeff=7.667, $t=2.55$ ). Among firm-specific variables, LEV shows a negative and significant association with COVID_dummy at 5\% level (coeff=-4.6852, $t=-2.53)$. TOBINSQ shows to have a negative and significant association with COVID_score at $10 \%$ level (coeff $=-5.0124, t=-1.72)$ 
and with COVID_dummy at 5\% level (coeff=-6.162, $t=-2.27$ ) and LOSS is positive and significant with COVID_score at $5 \%$ level (coeff $=1.968, t=2.53$ ) and with COVID_dummy at 5\% level (coeff $=1.9117, t=2.12)$ suggesting that companies that are less profitable and companies that are incurring losses are more likely to be disclosing COVID-related information in CSR reports. Managers of companies suffering from financial constraints might have more pressures about the firm current performance and disclose more information about COVID19 engagement practices.

Our results for the sample of small firms are less significant for our variables of interest, and only Assurance_type shows to be positive and significant at $10 \%$ level. The demand for assurance may place an increased drain on resource use when there is an insufficient market for resources (Al-Shaer and Zaman, 2018). This is more likely to pertain to small firms and explain the weaker effects of CSR external assurance and assurance provider on COVID-related disclosures. Small firms may perceive that the incremental cost of external assurance outweighs the benefits, and such costs are hard to overcome, especially during the COVID-19 pandemic that affects the world economy and threatens firms' survival.

\section{[Table $\mathrm{V}$ about here]}

We examine the impact of CSR sensitive industries in Table VI. We include industry as a categorical variable following Sierra et al. (2013) and Al-Shaer and Zaman (2018) and assign a value of $1-5$ based on firms' CSR-sensitive activities. ${ }^{4}$ We assign a value of 1 if the company belongs to technology and telecommunication industry, a value of 2 if the company belongs to consumer services and health care industry, a value of 3 if the company belongs to

\footnotetext{
${ }^{4}$ We have 14 companies out of $243(5.76 \%)$ belong to technology and telecommunication industry, 166 companies out of $243(68.31 \%)$ belong to consumer services and health care industries, 35 companies out of 243 (14.4\%) belong to consumer goods industry, and 7 companies out of $243(11.11 \%)$ belong to basic materials, utilities, and construction industries. We have only one company that belongs to the oil and gas industry.
} 
consumer goods industry, a value of 4 if the company belongs to necessary materials, utilities and construction industry, and a value of 5 if the company belongs to oil and gas industry. Our findings are consistent with previous findings presented in Table IV and show that the existence of independent external assurance and the type of assurer have a positive and significant association with both COVID_score and COVID_dummy. Overall, findings in Tables V and VI support our hypothesis on the heterogeneity in the impact of assurance and assurance provider on COVID-related disclosures in CSR reports when considering different firms' size and different CSR sensitive industries.

\section{[Table VI about here]}

\section{SUMMARY AND CONCLUSIONS}

The COVID-19 pandemic has been affecting the global economy and adding pressures on companies to commit to their CSR matters during the crisis. Companies are facing challenging decisions regarding their social and ethical behaviour and they will need to respond proactively to protect their employees and customers (Levy, 2020). The independent external assurance of CSR reports helps enhance the transparency and credibility of reported information (Zorio et al., 2013). Companies' willingness to voluntary engage in the independent external assurance is likely to affect the level of COVID-related disclosures in CSR reports. This study investigates the impact of the existence of external assurance and the type of assurer on the disclosure of COVID-related information in CSR reports.

Based on a sample of UK firms that publish their annual reports in 2020, we use a computer-aided textual analysis and use a bag of words to captures the COVID-related information in the CSR section of firm's annual reports. Our findings show that the existence of independent external assurance has a positive and significant association with COVID- 
related information measured using both the frequency of words appearing in the reports (COVID_score) and a dummy variable (COVID_dummy). We also find that when assurance is provided by Big4 accountancy firm, the disclosure of COVID-related information is enhanced. We also divide the sample into large and small firms and find that large companies are more likely to disclose COVID-related information in their CSR reports that are externally assured from a top tier accountancy firm because they have the required resources to cover such cost than smaller firms. We further explore the influence of CSR-sensitive industries on the impact of CSR assurance and assurance provider on COVID-related disclosures, and our results are consistent.

During the COVID-19 pandemic, many companies have been accused of neglecting health risks of workers and customers (Levy, 2020). Corporate managers are responsible for engaging in CSR initiatives that use CSR disclosure choices as an 'insurance-like' protection (Lee, 2020, Stuart et al., 2020) that would emphasise health and community resilience (Levy, 2020). Companies will need to signal their ethical behaviour during the pandemic through CSR disclosures and the voluntary purchase of CSR assurance to mitigate the risks from irresponsible activities (e.g., safety or health issues) and protect their reputation and survival. Even though CSR assurance is still trailing among many companies, smaller companies in particular, due to its voluntary nature and cynicism about its net benefit (Stuart et al., 2020), a company that voluntary undertakes CSR assurance helps enhance perceptions of its ethical culture and intention to make disclosures subject to independent assessments (Stuart et al., 2020).

We recognise the heavy impact of the COVID-19 pandemic on companies' financial resilience and the underlying effect of the current economic crisis on corporate commitments to CSR. Managers will need to assess the costs and benefits of purchasing assurance on CSR disclosures giving the ethical signal that CSR assurance sends to the market and protection 
that it covers during negative events (Stuart et al., 2020). Assurance signals a positive ethical culture and removes the burdens otherwise associated with businesses' self-serving motives (Bagnoli and Watts, 2017). From a regulatory perspective, standard-setters and policymakers could consider issuing guidelines and establish reporting regulations for CSR disclosure practices to develop CSR policies in times of crisis. This might increase corporate engagement with CSR and improve sustainable performance. The success of such initiatives however will depend, inter-alia, on the disclosure of credible CSR related information. Our findings may help to inform regulators of the importance of CSR assurance choices in providing protection during the pandemic.

Our paper has a few limitations that provide opportunities for future research. The findings are restricted to UK companies that published their annual reports in the first half of 2020. Future study can expand on the sample size to get an overview of COVID-19 disclosure and capture the changes of reporting practices. Future research can investigate whether new CSR initiatives emerge during the pandemic (Lee, 2020), which will impact on existing CSR disclosures and assurance choices. Finally, research can also supplement our study by conducting interviews with various assurance providers and providing insights into CSR assurance providers' role within particular organisational and institutional settings during or after the pandemic. 


\section{REFERENCES}

Albitar, K., Gerged, A. M., Kikhia, H., and Hussainey, K. (2020a), “Auditing in times of social distancing: the effect of COVID-19 on auditing quality", International Journal of Accounting and Information Management. In Press.

Albitar, K., Hussainey, K., Kolade, N., and Gerged, A. M. (2020b), “ESG disclosure and firm performance before and after IR", International Journal of Accounting and Information Management, Vol. 28 No. 3, pp. 429-444.

Al-Shaer, H. (2020), "Sustainability reporting quality and post-audit financial reporting quality: Empirical evidence from the UK", Business Strategy and the Environment, Vol. 29 No. 6, pp. 2355-2373.

Al-Shaer, H., and Zaman, M. (2018), “Credibility of sustainability reports: The contribution of audit committees", Business Strategy and the Environment, Vol. 27 No. 7, pp. 973-986.

Al-Shaer, H., and Zaman, M. (2019), "CEO compensation and sustainability reporting assurance: Evidence from the U.K", Journal of Business Ethics, Vol. 158 No. 1, pp. 233252.

Al-Shaer, H., Salama, A., and Toms, S. (2017), "Audit committees and financial reporting quality: Evidence from U.K. environmental accounting disclosures", Journal of Applied Accounting Research, Vol. 18 No 1, pp. 2-21.

Amankwah-Amoah, J. (2020), "Stepping up and stepping out of COVID-19: New challenges for environmental sustainability policies in the global airline industry", Journal of Cleaner Production, Vol. 271, pp. 123000.

Andreou, P. C., Harris, T., and Philip, D. (2020), "Measuring Firms' Market Orientation Using Textual Analysis of 10-K Filings", British Journal of Management, Vol. 31 No. 4, pp. 872895.

Bagnoli, M., and Watts, S. G. (2017), "Voluntary assurance of voluntary CSR disclosure", Journal of Economics and Management Strategy, Vol 26 No. 1, pp. 205-230.

Ballou, B., Chen, P. C., Grenier, J. H., and Heitger, D. L. (2018), “Corporate social responsibility assurance and reporting quality: Evidence from restatements", Journal of Accounting and Public Policy, Vol. 37 No. 2, pp. 167-188.

Barkemeyer, R., Comyns, B., Figge, F., and Napolitano, G. (2014), "CEO statements in sustainability reports: Substantive information or background noise?", Accounting Forum, Vol. 38, pp. 241-257.

Barney, J. B., Wright, M. and Ketchen, D. J. (2001), “The resource based view of the firm: ten years after 1991", Journal of Management, Vol. 27, pp. 625-643.

Birkey, R. N., Michelon, G., Patten, D. M., and Sankara, J. (2016), “Does assurance on CSR reporting enhance environmental reputation? An examination in the U.S. context", Accounting Forum, Vol. 40 No. 3, pp. 143-152.

Boiral, O., Heras-Saizarbitoria, I., and Brotherton, M. C. (2019), "Assessing and improving the quality of sustainability reports: The auditors' perspective", Journal of Business Ethics, Vol. 155 No. 3, pp. 703-721.

Boiral, O., and Heras-Saizarbitoria, I. (2020), "Sustainability reporting assurance: Creating stakeholder accountability through hyperreality?", Journal of Cleaner Production, Vol. 243 , pp. 118596.

Broadstock, D. C., Chan, K., Cheng, L. T. and Wang, X., (2020), “The role of ESG performance during times of financial crisis: Evidence from COVID-19 China", Finance Research Letters, In Press.

Campbell, D. (2003), "Intra- and intersectoral effects in environmental disclosures: evidence for legitimacy theory?", Business Strategy and the Environment, Vol. 12 No. 6, pp. 357371. 
Chan, S. H., Creel, T. S., Song, Q., and Yurova, Y. V. (2020), “Does CSR reporting indicate strong corporate governance?", International Journal of Accounting and Information Management. In Press.

Chen, L., Srinidhi, B., Tsang, A., and Yu, W. (2016), "Audited financial reporting and voluntary disclosure of corporate social responsibility (CSR) reports", Journal of Management Accounting Research, Vol. 28 No. 2, pp. 53-76.

Clarkson, P. M., Li, Y., Richardson, G., and Tsang, A. (2015), “Voluntary external assurance of corporate social responsibility reports and the Dow Jones Sustainability Index membership: International evidence", Unpublished working paper, UQ Business School.

Clarkson, P., Li, Y., Richardson, G., and Tsang, A. (2019), "Causes and consequences of voluntary assurance of CSR reports", Accounting, Auditing and Accountability Journal, Vol. 32 No. 8, pp. 2451-2474.

Cohen, J. R., and Simnett, R. (2015), "CSR and assurance services: A research agenda", Auditing: A Journal of Practice and Theory, Vol. 34 No. 1, pp. 59-74.

Dawkins, C. E., and Fraas, J. W. (2011), "Erratum to: Beyond acclamations and excuses: environmental performance, voluntary environmental disclosure and the role of visibility" Journal of Business Ethics, Vol. 99 No. 3, pp. 383-397.

Deegan, C., Rankin, M., and Voght, P. (2000), "Firms' disclosure reactions to major social incidents: Australian evidence", Accounting forum, Vol. 24 No 1, pp. 101-130.

Donthu, N., and Gustafsson, A. (2020), "Effects of COVID-19 on business and research", Journal of business research, Vol. 117, pp. 284.

Du, K., and Wu, S. J. (2019), "Does external assurance enhance the credibility of CSR reports? Evidence from CSR-related misconduct events in Taiwan", Auditing: A Journal of Practice and Theory, Vol. 38 No. 4, pp. 101-130.

El-Haj, M., Alves, P., Rayson, P., Walker, M., and Young, S. (2019), "Retrieving, classifying and analysing narrative commentary in unstructured (glossy) annual reports published as PDF files", Accounting and Business Research, Vol. 50 No. 1, pp. 6-34.

Elmarzouky, M., Albitar, K., Karim, A. E., and Moussa, A. S. (2020), “COVID-19 disclosure: a novel measurement and annual report uncertainty. Available at: https://www.researchgate.net/publication/348393802

Erdem, O., (2020), "Freedom and stock market performance during Covid-19 outbreak", Finance Research Letter, Vol. 36.

Farooq, M. B., and De Villiers, C. (2019), "The shaping of sustainability assurance through the competition between accounting and non-accounting providers", Accounting, Auditing and Accountability Journal, Vol. 32 No. 1, pp. 307-336

Fernandez-Feijoo, B., Romero, S., and Ruiz, S. (2015), “Multilevel approach to sustainability report assurance decisions", Australian Accounting Review, Vol. 25 No. 4, pp. 346-358.

Fisher, R., van Staden, C. and Richards, G. (2019), "Watch that tone: An investigation of the use and stylistic consequences of tone in corporate accountability disclosures", Accounting, Auditing and Accountability Journal, Vol. 33 No. 1, pp. 77-105.

Gerged, A. M., Cowton, C. J., and Beddewela, E. S. (2018), “Towards sustainable development in the Arab Middle East and North Africa region: A longitudinal analysis of environmental disclosure in corporate annual reports", Business Strategy and the Environment, Vol. 27 No. 4, pp. 572-587

Goodell, J. W. (2020), “COVID-19 and finance: Agendas for future research", Finance Research Letters, Vol. 101512.

GOV.UK. (2020). Working safely during coronavirus (COVID-19) - Guidance - GOV.UK. [ONLINE] Available at: https://www.gov.uk/guidance/working-safely-duringcoronavirus-Covid-19. [Accessed 18th September 2020]. 
Gürtürk, A., and Hahn, R. (2016), "An empirical assessment of assurance statements in sustainability reports: Smoke screens or enlightening information?" Journal of Cleaner Production, Vol. 136, pp. 30-41.

Hassan, A., Elamer, A. A., Fletcher, M., and Sobhan, N. (2020), "Voluntary assurance of sustainability reporting: Evidence from an emerging economy", Accounting Research Journal (forthcoming).

He, H., and Harris, L. (2020), "The Impact of Covid-19 Pandemic on Corporate Social Responsibility and Marketing Philosophy", Journal of Business Research. In press.

Hodge, K., Subramaniam, N., and Stewart, J. (2009), "Assurance of sustainability reports: Impact on report users' confidence and perceptions of information credibility", Australian Accounting Review, Vol. 19 No. 3, pp. 178-194.

Hossain, M. (2020), "The effect of the Covid-19 on sharing economy activities", Journal of Cleaner Production, Vol. 280, pp. 124782.

Hummel, K., Schlick, C., and Fifka, M. (2019), "The role of sustainability performance and accounting assurors in sustainability assurance engagements", Journal of Business Ethics, Vol. 154 No 3, pp. 733-757.

Husted, B. W., and de Sousa-Filho, J. M. (2019), “Board structure and environmental, social, and governance disclosure in Latin America", Journal of Business Research, Vol. 102, pp. 220-227.

Junior, R.M., Best, P.J., and Cotter, J. (2014), "Sustainability reporting and assurance: a historical analysis on a worldwide phenomenon", Journal of Business Ethics, Vol. 120 No 1, pp. 1-11.

Ioannou, I., and Serafeim, G. (2012), "What drives corporate social performance? The role of nation-level institutions", Journal of International Business Studies, Vol. 43 No. 9, pp. 834864.

Lee, S. (2020), "Corporate social responsibility and COVID-19: Research implications", Tourism Economics. In press

Levy, D. L. (2020), “COVID-19 and Global Governance”. Journal of Management Studies. In press.

Li, Z., Liao, G., and Albitar, K. (2020), "Does corporate environmental responsibility engagement affect firm value? The mediating role of corporate innovation", Business Strategy and the Environment, Vol. 29 No. 3, pp. 1045-1055.

Liao, G., Hou, P., Shen, X., and Albitar, K. (2020), “The impact of economic policy uncertainty on stock returns: The role of corporate environmental responsibility engagement", International Journal of Finance \& Economics. In press.

Linsley, P. M., and Shrives, P. J. (2006), "Risk reporting: A study of risk disclosures in the annual reports of U.K. companies", The British Accounting Review, Vol. 38 No. 4, pp. 387-404.

Loughran, T., and McDonald, B. (2011), "When is a liability not a liability? Textual analysis, dictionaries, and 10-Ks", The Journal of Finance, Vol. 66 No. 1, pp. 35-65.

Mahoney, L. S., Thorne, L., Cecil, L., and LaGore, W. (2013), “A research note on standalone corporate social responsibility reports: Signaling or greenwashing?", Critical perspectives on Accounting, Vol. 24, pp. 350-359.

Majumder, M. T. H., Akter, A., and Li, X. (2017), “Corporate governance and corporate social disclosures: a meta-analytical review", International Journal of Accounting and Information Management, Vol. 25 No. 4, pp. 434-458.

Manuel, T., and Herron, T. L. (2020), "An ethical perspective of business CSR and the COVID19 pandemic", Society and Business Review. In press.

Martínez-Ferrero, J., García-Sánchez, I. M., and Ruiz-Barbadillo, E. (2018), “The quality of sustainability assurance reports: The expertise and experience of assurance providers as determinants", Business Strategy and the Environment, Vol. 27 No. 8, pp. 1181-1196. 
Mazur, M., Dang, M. and Vega, M., (2020), “COVID-19 and the March 2020 stock market crash. Evidence from SandP1500", Finance Research Letters. In Press.

Michelon, G., Patten, D.M. and Romi, A.M. (2019), "Creating legitimacy for sustainability assurance practices: evidence from sustainability restatements", European Accounting Review, Vol. 28 No. 2, pp. 395-422.

Milne, M. J. (2002), "Positive accounting theory, political costs and social disclosure analyses: A critical look", Critical perspectives on accounting, Vol. 13 No. 3, pp. 369-395.

Muslu, V., Mutlu, S., Radhakrishnan, S., and Tsang, A. (2019), “Corporate social responsibility report narratives and analyst forecast accuracy", Journal of Business Ethics, Vol. 154 No 4, pp. 1119-1142.

Nazari, J. A., Hrazdil, K., and Mahmoudian, F. (2017), “Assessing social and environmental performance through narrative complexity in CSR reports", Journal of Contemporary Accounting and Economics, Vol. 13 No. 2, pp. 166-178.

Perego, P., and Kolk, A. (2012), "Multinationals' accountability on sustainability: The evolution of third-party assurance of sustainability reports", Journal of Business Ethics, Vol. 110 No. 2, pp. 173-190.

Pflugrath, G., Roebuck, P., and Simnett, R. (2011), “Impact of assurance and assurer's professional affiliation on financial analysts' assessment of credibility of corporate social responsibility information", Auditing: A Journal of Practice and Theory, Vol. 30 No. 3, pp. 239-254.

Russo, M. V. and Fouts, P. A. (1997), “A resource-based perspective on corporate environmental performance and profitability", The Academy of Management Journal, Vol. 40 No. 3, pp. 534-559.

Ruiz-Barbadillo, E., and Martínez-Ferrero, J. (2020), "Empirical analysis of the effect of the joint provision of audit and sustainability assurance services on assurance quality", Journal of Cleaner Production, pp. 121943.

Salisu, A. A. and Vo, X. V., (2020), "Predicting stock returns in the presence of COVID-19 pandemic: The role of health news", International Review of Financial Analysis, Vol. 71.

Severo, E. A., De Guimarães, J. C. F., and Dellarmelin, M. L. (2020), "Impact of the COVID-19 pandemic on environmental awareness, sustainable consumption and social responsibility: Evidence from generations in Brazil and Portugal", Journal of Cleaner Production, pp. 124947.

Simnett, R., Vanstraelen, A., and Chua, W. F. (2009), “Assurance on sustainability reports: An international comparison", The Accounting Review, Vo. 84 No. 3, pp. 937-967.

Sierra, L., Zorio, A., and García-Benau, M. A. (2013), “Sustainable development and assurance of corporate social responsibility reports published by Ibex-35 companies", Corporate Social Responsibility and Environmental Management, Vol. 20 No. 6, pp.359-370.

Stuart, A. C., Bedard, J. C., and Clark, C. E. (2020), "Practitioner Summary: The Value of Assurance and Ethics in Difficult Times: Corporate Social Responsibility Disclosures and Investor Decisions. Current Issues in Auditing. In press.

Ullah, M. S., Muttakin, M. B., and Khan, A. (2019), “Corporate governance and corporate social responsibility disclosures in insurance companies", International Journal of Accounting and Information Management, Vol. 27 No. 2, pp. 284-300

Watts, R. L. and Zimmerman, J. L. (1979), “The demand for and supply of accounting theories: the market for excuses", The Accounting Review, Vol. 54 No. 2, pp. 273-305.

Zorio, A., García-Benau, M. A., and Sierra, L. (2013), "Sustainability development and the quality of assurance reports: Empirical evidence", Business strategy and the environment, Vol. 22 No. 7, pp. 484-500. 
Table 1: Variables Definition

\begin{tabular}{ll}
\hline CSR Assurance & $=1$ if CSR information is externally assured, 0 otherwise. \\
CSR Assurance Provider & $=3$ if assurance is provided by Big4 accounting firm; 2 if assurance is \\
& provided by non-Big4 accounting firm; 1 if assurance is provided by non- \\
& accounting firm; 0 if no assurance service is provided \\
& $=1$ if a board level sustainability committee exists, 0 otherwise. \\
& ESG performance composite measure generated from a weighted score of \\
SUSCOM & firms' social, environmental and governance indicators from Thomson \\
ESG_perf & Reuters' Assets4 (in previous year). \\
& Number of directors on the board \\
BODSIZE & Proportion of independent directors on the board \\
BODIND & Proportion of female directors on the board \\
BODDIV & Debt to total asset ratio \\
LEV & Return on assets ratio measured by net income to total assets \\
ROA & Sum of firm equity value, book value of long-term debt, and current \\
TOBINSQ & liabilities divided by total asset \\
& An indicator variable equal to one when the current year's net income is \\
LOSS & negative, and zero otherwise \\
SIZE & Natural log of total assets \\
Length & Length of the document measured by the natural log of total number of \\
& words in the CSR section \\
IND & Industry dummy. Grouping industries using the DataStream Industry \\
& Classification Benchmark (ICB) Level 1 industries, creating ten groups \\
\hline
\end{tabular}


Table 2: Descriptive Statistics

\begin{tabular}{lccccc}
\hline Variables & $\mathrm{N}$ & Mean & SD & Min & Max \\
\hline COVID_score & 243 & 1.646091 & 4.806832 & 0 & 40 \\
COVID_dummy & 243 & 0.3333333 & 0.4723775 & 0 & 1 \\
CSR_assurance & 243 & 0.6588235 & 0.4755051 & 0 & 1 \\
Assurance_type & 243 & 0.7613169 & 0.8817628 & 0 & 3 \\
SUSCOM & 243 & 0.7283951 & 0.4457053 & 0 & 1 \\
ESG_perf & 242 & 102.4909 & 31.30142 & 28.43861 & 185.5065 \\
BODSIZE & 243 & 8.584362 & 2.101771 & 4 & 16 \\
BODIND & 243 & 0.6083462 & 0.1429224 & 0.125 & 1 \\
BODDIV & 243 & 0.2843536 & 0.1001816 & 0 & 0.5714286 \\
LEV & 243 & 0.6900631 & 1.879777 & -14.51104 & 7.844407 \\
ROA & 243 & 0.0473287 & 0.0864786 & -0.4222273 & 0.4379708 \\
TOBINSQ & 243 & 0.8777013 & 0.1076318 & 0.3155324 & 1.00014 \\
LOSS & 243 & 0.8436214 & 0.3639636 & 0 & 1 \\
TOTAL ASSETS & 243 & 8380000000 & 30900000000 & 91100000 & 295000000000 \\
Readability & 243 & 41.06513 & 30.05657 & -106.8853 & 248.9067 \\
\hline \multicolumn{4}{c}{ Variables winsorised to adjust for outliers. Variables are as defined in Table 1. } & &
\end{tabular}




\section{Table 3: Correlation Matrix}

\begin{tabular}{|c|c|c|c|c|c|c|c|c|c|c|c|c|c|c|}
\hline Variables & 1 & 2 & 3 & 4 & 5 & 6 & 7 & 8 & 9 & 10 & 11 & 12 & 13 & 14 \\
\hline COVID_dummy & 1 & & & & & & & & & & & & & \\
\hline CSR_assurance & 0.3162 & 1 & & & & & & & & & & & & \\
\hline Assurance_type & 0.2910 & 0.7107 & 1 & & & & & & & & & & & \\
\hline SUSCOM & 0.1178 & 0.0268 & 0.0762 & 1 & & & & & & & & & & \\
\hline ESG_perf & 0.2268 & 0.1630 & 0.1934 & 0.4581 & 1 & & & & & & & & & \\
\hline BODSIZE & 0.061 & 0.0277 & 0.1402 & 0.2981 & 0.2572 & 1 & & & & & & & & \\
\hline BODIND & 0.0227 & -0.0491 & 0.0751 & 0.0731 & 0.1929 & 0.0312 & 1 & & & & & & & \\
\hline BODDIV & 0.1310 & -0.0154 & 0.0534 & 0.0886 & 0.2933 & 0.0557 & 0.2896 & 1 & & & & & & \\
\hline LEV & 0.0506 & 0.1317 & 0.1634 & 0.0311 & -0.0143 & -0.0133 & 0.0044 & 0.0585 & 1 & & & & & \\
\hline ROA & -0.0654 & 0.0802 & 0.006 & -0.0769 & -0.0278 & -0.0092 & 0.1127 & 0.1454 & -0.1296 & 1 & & & & \\
\hline TOBINSQ & -0.1017 & 0.0752 & -0.0113 & -0.2004 & -0.1643 & -0.1232 & 0.0296 & -0.0402 & -0.1117 & 0.2145 & 1 & & & \\
\hline LOSS & 0.0401 & 0.0165 & 0.0506 & -0.0846 & -0.0244 & 0.0281 & 0.1952 & 0.1027 & -0.0507 & 0.6196 & 0.0691 & 1 & & \\
\hline SIZE & 0.1496 & 0.0936 & 0.3103 & 0.3479 & 0.4187 & 0.5547 & 0.1937 & 0.2415 & 0.2049 & -0.1373 & -0.2722 & -0.0086 & 1 & \\
\hline Readability & 0.3369 & 0.083 & 0.0497 & -0.0451 & -0.0262 & -0.0926 & -0.039 & -0.1026 & 0.0979 & -0.0329 & -0.0288 & 0.1069 & -0.0234 & 1 \\
\hline
\end{tabular}


Table 4: Regression Results for the Full Sample

\begin{tabular}{|c|c|c|}
\hline & Negative Binomial Regression & Probit Regression \\
\hline Variables & COVID_score & COVID_dummy \\
\hline \multirow[t]{2}{*}{ CSR_assurance } & $1.2408^{* *}$ & $0.7095^{* *}$ \\
\hline & [2.21] & [1.98] \\
\hline \multirow[t]{2}{*}{ Assurance_Type } & $0.5399 * * *$ & $0.5453^{* * *}$ \\
\hline & [2.69] & [3.03] \\
\hline \multirow[t]{2}{*}{ SUSCOM } & 0.0177 & 0.0655 \\
\hline & {$[0.04]$} & {$[0.22]$} \\
\hline \multirow[t]{2}{*}{ ESG_perf } & 0.1323 & 0.0337 \\
\hline & [1.03] & {$[0.38]$} \\
\hline \multirow[t]{2}{*}{ BODSIZE } & 0.445 & $0.183^{*}$ \\
\hline & {$[0.58]$} & {$[1.38]$} \\
\hline \multirow[t]{2}{*}{ BODIND } & -0.5206 & -0.3079 \\
\hline & {$[-0.48]$} & {$[-0.32]$} \\
\hline \multirow[t]{2}{*}{ BODDIV } & $4.4199 * *$ & $4.0573^{* * *}$ \\
\hline & {$[2.50]$} & [3.28] \\
\hline \multirow[t]{2}{*}{ LEV } & -0.0822 & $-1.6579 * *$ \\
\hline & {$[-0.67]$} & {$[-2.01]$} \\
\hline \multirow[t]{2}{*}{ ROA } & -2.416 & -2.3803 \\
\hline & {$[-0.87]$} & {$[-1.41]$} \\
\hline \multirow[t]{2}{*}{ TOBINSQ } & -1.4655 & -1.0447 \\
\hline & {$[-0.83]$} & {$[-0.80]$} \\
\hline \multirow[t]{2}{*}{ LOSS } & -0.0874 & -0.0647 \\
\hline & {$[-0.16]$} & {$[-0.14]$} \\
\hline \multirow[t]{2}{*}{ SIZE } & -0.2068 & -0.1661 \\
\hline & {$[-1.35]$} & {$[-1.44]$} \\
\hline \multirow[t]{2}{*}{ Readability } & $0.0253^{* * *}$ & $0.0172^{* * *}$ \\
\hline & [5.94] & [2.78] \\
\hline IND & Included & Included \\
\hline \multirow[t]{2}{*}{ Intercept } & -2.0035 & 0.046 \\
\hline & {$[-0.60]$} & {$[0.02]$} \\
\hline Wald chi2(14) & 58.12 & 45.24 \\
\hline R-squared & & 0.2819 \\
\hline $\mathrm{N}$ & 243 & 243 \\
\hline
\end{tabular}


Table 5: Additional Analysis: Size Effect

\begin{tabular}{|c|c|c|c|c|}
\hline & \multicolumn{2}{|c|}{ Large Firms } & \multicolumn{2}{|c|}{ Small firms } \\
\hline & Probit & Negative Binomial & Probit & Negative Binomial \\
\hline Variable & COVID_dummy & COVID_score & COVID_dummy & COVID_score \\
\hline CSR_assurance & $\begin{array}{c}1.6097^{* *} \\
{[2.32]}\end{array}$ & $\begin{array}{c}1.6440^{*} \\
{[1.74]}\end{array}$ & $\begin{array}{c}-0.8183 \\
{[-0.90]}\end{array}$ & $\begin{array}{c}0.6295 \\
{[0.67]}\end{array}$ \\
\hline Assurance_type & $\begin{array}{c}0.5394^{* *} \\
{[2.12]}\end{array}$ & $\begin{array}{c}0.5357^{* *} \\
{[1.69]}\end{array}$ & $\begin{array}{c}1.5722^{*} \\
{[2.41]}\end{array}$ & $\begin{array}{c}0.9736^{*} \\
{[2.23]}\end{array}$ \\
\hline SUSCOM & $\begin{array}{l}0.2599 \\
{[0.45]}\end{array}$ & $\begin{array}{c}0.0846 \\
{[0.13]}\end{array}$ & $\begin{array}{l}0.1895 \\
{[0.33]}\end{array}$ & $\begin{array}{l}-0.0855 \\
{[-0.13]}\end{array}$ \\
\hline ESG_perf & $\begin{array}{l}0.1659 \\
{[0.97]}\end{array}$ & $\begin{array}{l}0.0937 \\
{[0.41]}\end{array}$ & $\begin{array}{l}0.0888 \\
{[0.60]}\end{array}$ & $\begin{array}{l}0.1266 \\
{[0.59]}\end{array}$ \\
\hline BODSIZE & $\begin{array}{c}\mathbf{0 . 2 7 6 1 * *} \\
{[2.46]}\end{array}$ & $\begin{array}{c}1.7434^{*} \\
{[1.70]}\end{array}$ & $\begin{array}{l}-0.141 \\
{[-0.89]}\end{array}$ & $\begin{array}{c}-1.0079 \\
{[-0.71]}\end{array}$ \\
\hline BODIND & $\begin{array}{c}-3.9742^{*} \\
{[-1.85]}\end{array}$ & $\begin{array}{c}-0.6175 \\
{[-0.26]}\end{array}$ & $\begin{array}{c}-0.9865 \\
{[-0.71]}\end{array}$ & $\begin{array}{c}-2.2276 \\
{[-1.41]}\end{array}$ \\
\hline BODDIV & $\begin{array}{c}8.6329 * * * \\
{[2.87]}\end{array}$ & $\begin{array}{c}7.6670^{* *} \\
{[2.55]}\end{array}$ & $\begin{array}{c}4.3271^{* *} \\
{[1.99]}\end{array}$ & $\begin{array}{c}5.4125^{* *} \\
{[2.03]}\end{array}$ \\
\hline LEV & $\begin{array}{c}-4.6852^{* *} \\
{[-2.53]}\end{array}$ & $\begin{array}{c}-0.0864 \\
{[-0.34]}\end{array}$ & $\begin{array}{l}0.1558 \\
{[0.10]}\end{array}$ & $\begin{array}{c}-0.1124 \\
{[-0.55]}\end{array}$ \\
\hline ROA & $\begin{array}{c}2.8294 \\
{[0.51]}\end{array}$ & $\begin{array}{l}4.7873 \\
{[0.89]}\end{array}$ & $\begin{array}{c}-2.8594 \\
{[-0.73]}\end{array}$ & $\begin{array}{r}-4.9788 \\
{[-1.11]}\end{array}$ \\
\hline TOBINSQ & $\begin{array}{c}-6.1620^{* *} \\
{[-2.27]}\end{array}$ & $\begin{array}{c}-5.0124^{*} \\
{[-1.72]}\end{array}$ & $\begin{array}{c}0.1785 \\
{[0.06]}\end{array}$ & $\begin{array}{c}-1.6618 \\
{[-0.45]}\end{array}$ \\
\hline LOSS & $\begin{array}{c}-1.9117^{* *} \\
{[-2.12]}\end{array}$ & $\begin{array}{c}-1.9680^{* *} \\
{[-2.53]}\end{array}$ & $\begin{array}{l}1.074 \\
{[1.05]}\end{array}$ & $\begin{array}{l}1.5782 \\
{[1.37]}\end{array}$ \\
\hline SIZE & $\begin{array}{c}-0.2814 \\
{[-1.46]}\end{array}$ & $\begin{array}{r}-0.3447 \\
{[-1.40]}\end{array}$ & $\begin{array}{l}0.4477 \\
{[1.02]}\end{array}$ & $\begin{array}{c}0.2266 \\
{[0.44]}\end{array}$ \\
\hline Readability & $\begin{array}{c}0.0248^{* * *} \\
{[3.35]}\end{array}$ & $\begin{array}{c}0.0318^{* * *} \\
{[4.85]}\end{array}$ & $\begin{array}{c}0.0302^{*} \\
{[1.79]}\end{array}$ & $\begin{array}{c}0.0239 * * * \\
{[3.47]}\end{array}$ \\
\hline IND & Included & Included & Included & Included \\
\hline Intercept & $\begin{array}{c}5.6352 \\
{[1.21]}\end{array}$ & $\begin{array}{c}2.6575 \\
{[0.43]}\end{array}$ & $\begin{array}{c}-14.2716 \\
{[-1.50]}\end{array}$ & $\begin{array}{c}-8.5895 \\
{[-0.78]}\end{array}$ \\
\hline Wald chi2(14) & 44.52 & 51.11 & 35.83 & 32.45 \\
\hline R-squared & 0.4103 & & 0.3666 & \\
\hline $\mathrm{N}$ & 88 & 88 & 80 & 80 \\
\hline
\end{tabular}


Table 6: Additional Analysis: Industry Effect

\begin{tabular}{|c|c|c|}
\hline & $\begin{array}{c}\text { Negative Binomial } \\
\text { Regression }\end{array}$ & Probit Regression \\
\hline Variable & COVID_score & COVID_dummy \\
\hline CSR_assurance & $\begin{array}{c}0.7102^{* *} \\
{[1.97]}\end{array}$ & $\begin{array}{c}1.2436^{* *} \\
{[2.22]}\end{array}$ \\
\hline Assurance_type & 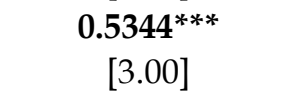 & $\begin{array}{c}0.5240^{* * *} \\
{[2.62]}\end{array}$ \\
\hline SUSCOM & $\begin{array}{l}0.0797 \\
{[0.27]}\end{array}$ & $\begin{array}{c}0.0373 \\
{[0.09]}\end{array}$ \\
\hline ESG_perf & $\begin{array}{l}0.0455 \\
{[0.51]}\end{array}$ & $\begin{array}{l}0.1386 \\
{[1.08]}\end{array}$ \\
\hline BODSIZE & $\begin{array}{l}0.0814 \\
{[1.38]}\end{array}$ & $\begin{array}{l}0.4819 \\
{[0.63]}\end{array}$ \\
\hline BODIND & $\begin{array}{l}-0.254 \\
{[-0.27]}\end{array}$ & $\begin{array}{l}-0.4229 \\
{[-0.40]}\end{array}$ \\
\hline BODDIV & $\begin{array}{c}4.001^{* * *} \\
{[3.25]}\end{array}$ & $\begin{array}{c}4.4272^{* *} \\
{[2.52]}\end{array}$ \\
\hline LEV & $\begin{array}{c}-1.6155^{* *} \\
{[-1.97]}\end{array}$ & $\begin{array}{l}-0.0675 \\
{[-0.56]}\end{array}$ \\
\hline ROA & $\begin{array}{l}-2.3715 \\
{[-1.37]}\end{array}$ & $\begin{array}{r}-2.4689 \\
{[-0.88]}\end{array}$ \\
\hline TOBINSQ & $\begin{array}{l}-0.9214 \\
{[-0.73]}\end{array}$ & $\begin{array}{r}-1.1643 \\
{[-0.68]}\end{array}$ \\
\hline LOSS & $\begin{array}{c}-0.0714 \\
{[-0.16]}\end{array}$ & $\begin{array}{r}-0.1131 \\
{[-0.20]}\end{array}$ \\
\hline SIZE & $\begin{array}{c}-0.1674 \\
{[-1.44]}\end{array}$ & $\begin{array}{c}-0.2118 \\
{[-1.38]}\end{array}$ \\
\hline Flesch & $\begin{array}{c}\mathbf{0 . 0 1 7 4} \\
{[2.84]}\end{array}$ & $\begin{array}{c}\mathbf{0 . 0 2 5 2 * * *} \\
{[5.94]}\end{array}$ \\
\hline Sustainability Sensitive Industries & Included & Included \\
\hline Wald chi2(14) & 59.63 & 45.85 \\
\hline Intercept & $\begin{array}{c}0.7944 \\
{[0.31]}\end{array}$ & $\begin{array}{r}-1.2057 \\
{[-0.37]}\end{array}$ \\
\hline R-squared & & 0.2839 \\
\hline 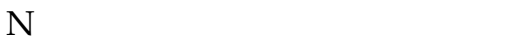 & 243 & 243 \\
\hline
\end{tabular}

${ }^{*} \mathrm{p}<0.1,{ }^{* *} \mathrm{p}<0.05,{ }^{* * *} \mathrm{p}<0.01$. Variables are as defined in Table 1

Following Sierra et al. (2013) and assign a value of 1-5 based on firms' CSR-sensitive activities. We assign a value of 1 if the company belongs to technology and telecommunication industry, a value of 2 if the company belongs to consumer services and health care industry, a value of 3 if the company belongs to consumer goods industry, a value of 4 if the company belongs to basic materials, utilities and construction industry, and a value of 5 if the company belongs to oil and gas industry. 